\title{
Susan A. Ostrander, Citizenship and Governance in a Changing City
}

\author{
Book Review
}

Marlene Walk

Susan A. Ostrander's book Citizenship and Governance in a Changing City is a valuable contribution to our understanding of the struggles newcomers face in the process of gaining full community membership. Ostrander, a professor at Tufts University, provides a fascinating community-level perspective on civic engagement, focusing specifically on the role of voluntary associations and their relationship to the civic and political life of Somerville, MA.

The book contains seven chapters. Chapter 1 sets the stage for the book, defines the key concepts, and describes the research setting and methods. Chapter 2 provides an historical and economical sketch of Somerville—a city that has long been described as "working-class," but where community development projects and an influx of middle-class young professionals has slowly changed this picture. Chapter 3 introduces the key voluntary and civic associations that have become a part of the public decision-making process. The experiences of both older and more recent immigrants are the focus of Chapter 4. Chapter 5 discusses immigrant civic and political engagement while also identifying potential barriers to participation. Chapter 6 describes Somerville residents’ views about the city’s future, the perceived advantages and disadvantages of gentrification, and a common vision for the city. The closing Chapter 7 critically examines who tends to hold elected positions in Somerville's city government in light of class, race, and immigration.

Citizenship is not solely about the political status, but also "the glue that binds strangers [...] in a political body [... and provides a sense of belonging” (Bloemraad 2006, p. 1). This sense of belonging is an essential part of what Ostrander defines as social citizenship. Social citizenship means being fully 
included into a community and serves as a precondition for democratic participation. Democratic participation is part of shared governance, "a process for making public decision that involves actors from both inside and outside government in an ongoing and dynamic way” (p. 2).

Based on 45 qualitative interviews, a review of city documents, and attendance at community and city meetings, Ostrander investigates the processes of civic participation in a historically immigrant city and finds that not all residents enjoy full social citizenship, regardless of their legal status. Residents mostly belong to one of three groups. The first group consists of longtime residents of Irish and Italian heritage, who were "born and raised” in Somerville and who dominate local politics. The second, constantly growing, group consists of middle-class predominantly white young professionals. Their influx into Somerville's neighborhoods started in the 1980s, when housing costs in nearby cities became unattainable. Newer immigrants from Central and South America form the third group. The last two groups are considered to be newcomers. Since they were not "born and raised" in Somerville, they have not achieved full social citizenship yet.

Ostrander illustrates the importance of voluntary associations for the achievement of full social citizenship and civic participation. She finds that immigrants, whether legally or illegally in the country, often need some protection before they feel safe enough to engage in public life. With their ability to advocate for the collective interests of their constituents, voluntary associations are believed to provide this safe environment.

But even with the engagement of voluntary associations in Somerville, Ostrander identifies a "deeper struggle that underlies much of the civil and political engagement in the city” (p. 18). This struggle is about local power. The city government does not reflect the diverse community of Somerville; none of the elected city officials belongs to a newcomer group. Even though elected city officials widely emphasize the importance of diversity in their community, they hold on to their power and seem to be interested in the maintenance of their vested rights as longtime residents. With an absence of political 
participation and full community membership of two large population groups, Ostrander reasons that “democracy itself weakens [which might lead to] a failure of democracy” (p. 148).

Citizenship and Governance in a Changing City is a fascinating book that illustrates the life world of three different groups, who all struggle with ongoing changes in their city. Thanks to this in-depth study the reader gets to know the city and its residents through the rich qualitative data and the excerpts that Ostrander provides throughout the text. The book is suitable for researchers and policy makers as well as community members with an interest in debates about the role of immigrants and other newcomers and their participation in urban civic and political life. It furthermore provides in-depth insights into the influence of voluntary associations in creating a space for immigrants' voices in a diverse and changing city. 


\section{References}

Bloemraad, I. (2006). Becoming a citizen: Incorporating immigrants and refugees in the U.S. and Canada.

Berkeley: University of California Press. 